\title{
Celowość prowadzenia prac badawczych nad nowymi środkami obniżającymi filtrację zaczynów cementowych
}

\begin{abstract}
W artykule zwrócono uwagę na konieczność prowadzenia specjalistycznych badań laboratoryjnych nad nowymi środkami przeznaczonymi do zaczynów cementowych. Podczas realizacji prac badawczych użyto nowego rodzaju domieszek, których zadaniem było zminimalizowanie wartości filtracji zaczynu cementowego. Głównym celem prac zaprezentowanych w niniejszej publikacji było zaprojektowanie zaczynu cementowego o niskiej wartości filtracji. W tym celu zastosowano trzy rodzaje domieszek antyfiltracyjnych. Dla porównania działania tych domieszek sporządzono próbkę zaczynu kontrolnego (bez środków regulujących filtrację zaczynu). We wszystkich zaczynach określono podstawowe parametry technologiczne, jednakże największe znaczenie miała wartość filtracji zaczynu cementowego. W celu określenia wpływu danej domieszki antyfiltracyjnej na pozostałe parametry zaczynu wykonane zostały badania w temperaturze $25^{\circ} \mathrm{C}$ i przy ciśnieniu $3 \mathrm{MPa}$. Ze względu na uzyskanie niespodziewanych wyników badań (w niektórych przypadkach otrzymano niemal sześciokrotny wzrost wartości filtracji po zastosowaniu domieszki antyfiltracyjnej) postanowiono upowszechnić efekty przeprowadzonych prac. Artykuł zawiera wyniki badań nad nowymi domieszkami antyfiltracyjnymi.
\end{abstract}

Słowa kluczowe: domieszka antyfiltracyjna, szczelność płaszcza cementowego, migracja gazu, filtracja zaczynu, parametry reologiczne.

\section{The purpose of conducting research for new fluid loss control agents for cement slurries}

This paper discusses the necessity of conducting specialized laboratory tests for new means/agents designed for cement slurries. During the execution of the research, new types of additives were used, in order to minimize the fluid loss of cement slurry. The main purpose of the research presented in this paper, was to design a cement slurry with low fluid loss value. For this purpose three types of fluid loss agents were used. To compare the impact of the fluid loss agent, a sample of base cement slurry (without additives regulating fluid loss of cement slurry) was prepared. The basic technological parameters were determined for all cement slurries, nonetheless, most significant was the fluid loss value of the cement slurry. In order to determine the effect of the fluid loss agent on other parameters, tests were conducted at a temperature of $25^{\circ} \mathrm{C}$ and at a pressure of $3 \mathrm{MPa}$. Due to the unexpected test results (in some cases almost a 6-fold increase in the fluid loss was obtained, after the application of the fluid loss agent) that were achieved it was decided to publish the results of the research. This paper presents the results of the research on innovative fluid loss agents.

Key words: fluid loss agent, tightness of cement sheath, gas migration, fluid loss, rheological parameters.

\section{Wprowadzenie}

Skuteczność przeprowadzenia zabiegu cementowania, a także późniejsza szczelność i trwałość powstałego płaszcza cementowego są w dużej mierze uzależnione od poprawnie zaprojektowanego składu zaczynu cementowego. W tym celu w Instytucie Nafty i Gazu - Państwowym Instytucie Badawczym realizowane są prace zmierzające w kierunku właściwego doboru parametrów stosowanych cieczy wiertniczych i zaczynów cementowych. Właści- wości zaczynów uszczelniających są dobierane lub odpowiednio modyfikowane dla konkretnych warunków geologiczno-technicznych, za pomocą specjalnego rodzaju domieszek. Przemysł chemiczny oferuje pomoc w postaci nowych związków chemicznych umożliwiających zmianę właściwości stosowanych cieczy wiertniczych. Jednakże przed wprowadzeniem danej domieszki do zaczynu i zastosowaniem jej w warunkach otworowych niezbędne 
jest wykonanie wielu czasochłonnych badań w laboratoriach INiG - PIB, przy użyciu specjalistycznej aparatury. W dalszej części publikacji omówione zostały wyniki prac badawczych pod kątem możliwości zastosowania nowego rodzaju domieszki mającej za zadanie obniżenie wartości filtracji zaczynu cementowego.

\section{Filtracja zaczynu i jej znaczenie w praktyce wiertniczej}

Zaczyn uszczelniający, aby mógł być zastosowany w warunkach przemysłowych, musi spełniać szereg restrykcyjnych wymagań. W tym celu jego parametry są regulowane za pomocą różnego rodzaju domieszek, umożliwiających stworzenie takiego zaczynu, który z powodzeniem będzie mógł być użyty w konkretnych warunkach geologiczno-technicznych [8, 11, 19, 20]. W dalszej części artykułu skupiono się głównie na nowym środku mającym za zadanie regulację filtracji zaczynu cementowego.

Stwardniały zaczyn cementowy powstaje wskutek hydratacji ziaren cementu z ok. 27 $\div 35$-procentową ilością wody $[15,16]$. Jednak tak sporządzony zaczyn jest całkowicie nieprzydatny do stosowania w praktyce wiertniczej (uszczelniania przestrzeni pierścieniowej). Dlatego też, aby poprawić reologię (płynność) zaczynu cementowego, stosuje się większą ilość wody zarobowej. Objętość ta jest powiększana niekiedy o $1,5 \div 2$ razy w stosunku do minimalnej ilości niezbędnej do hydratacji cementu. Uzależnione jest to od stopnia rozdrobnienia cementu oraz składu chemiczno-mineralogicznego danego spoiwa wiążącego $[16,21]$. Drugim sposobem obniżenia parametrów reologicznych jest zastosowanie środka dyspergującego (upłynniacza). Jednakże niezależnie od użytej domieszki, a tym samym - mechanizmu jej działania, w większym lub mniejszym stopniu wskutek sprzyjających warunków następuje oddzielenie się wody wolnej od zaczynu cementowego i znaczny wzrost filtracji zaczynu. Na taki stan rzeczy wpływ ma wiele czynników: począwszy od składu mineralogicznego, rozdrobnienia cementu, poprzez wartość stosunku wodno-cementowego, wartość temperatury, a skończywszy na rodzaju powierzchni formacji skalnej $[1,2,5,7,13]$.
Zaczyn cementowy, który charakteryzuje się dużymi wartościami filtracji, wykazuje znacznie szybsze gęstnienie, które następuje wskutek obniżania się pierwotnego współczynnika wodno-cementowego. Takie zachowanie zaczynu może być niebezpieczne z punktu widzenie samego procesu zatłaczania (zbyt wczesne wiązanie w przewodzie w trakcie tłoczenia). Ponadto zaczyn o wysokim wskaźniku filtracji zmniejsza swoją objętość, efektem czego jest „odklejanie" się stwardniałego zaczynu od formacji skalnej (rysunek 1) bądź rur okładzinowych. Niekiedy nawet mogą powstawać tzw. „kieszenie wodne” (rysunek 2) [16]. W zaczynach o dużej filtracji niekorzystnym czynnikiem jest również odfiltrowywanie wody w pokłady porowate złóż ropno-gazowych (rysunek 3), co prowadzi do szkodliwego oddziaływania na horyzonty produktywne. Działanie takie powoduje zmniejszenie przepuszczalności strefy przyodwiertowej złoża, co skutkuje wydłużeniem czasu potrzebnego do wywołania produkcji oraz zmniejszeniem wydajności odwiertu $[3,4,10,16]$. Zdarzyć się może obniżenie przepuszczalności polegające na tym, że skała nasycona filtratem z zaczynu może stać się całkowicie nieprzepuszczalna.

Ilość filtratu wpływa również na wielkość zmian współczynnika przepuszczalności kolektora. Zmiany te uzależnione są od parametrów zaczynu cementowego, jego składu chemicznego i mineralogicznego, a także od lepkości zaczynu oraz właściwości fizykochemicznych filtratu. Nieodwracalne zmiany współczynnika przepuszczalności formacji skalnej mogą być spowodowane wymywaniem cząstek oraz rozpuszczaniem składników złoża. Z kolei odwracalny charakter mają zmiany współczynnika przepuszczalności wywołane wymianą jonową. Dzieje się tak, ponieważ ośrodek nie

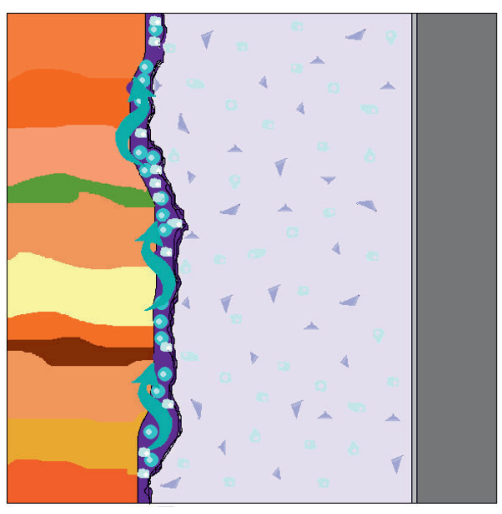

Rys. 1. Odklejanie się zaczynu od formacji skalnej

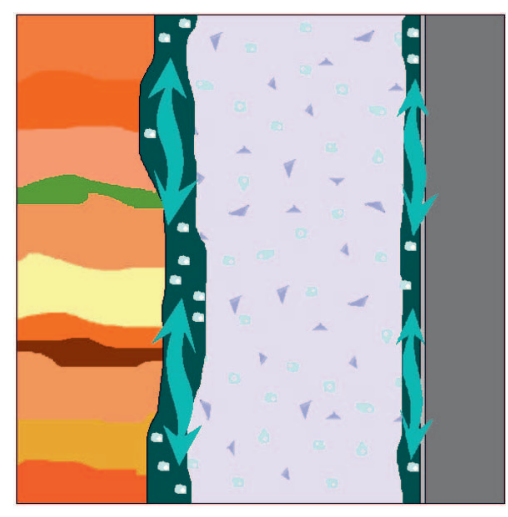

Rys. 2. Powstawanie „kieszeni wodnych"

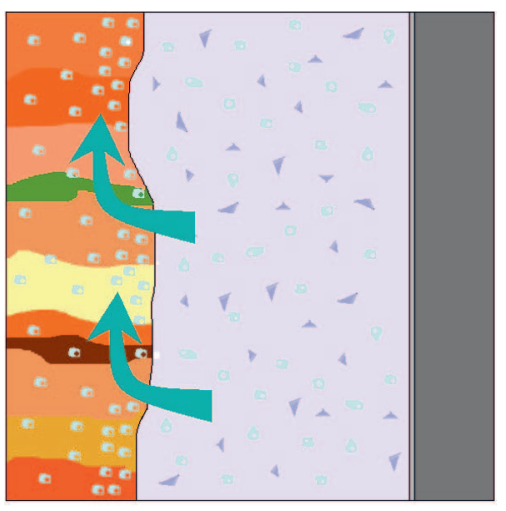

Rys. 3. Odfiltrowywania wody w pokłady porowate 
zmienia składu mineralogicznego ani granulometrycznego $[12,16]$. Tłumaczyć to można faktem, iż filtrat zawiera w składzie odpowiednie kationy i przy styku z ziarnami tworzącymi ośrodek porowaty istnieje możliwość ich wymiany. Konsekwencją tego jest zmiana zdolności adsorpcyjnej cząsteczek wody na powierzchni ziaren skały, czyli zmiana grubości otoczek solwatacyjnych.

Wspomnieć należy również o fakcie, że nadmierna filtracja zaczynu powoduje powstawanie takich odcinków podczas jego tłoczenia, w których zaczyn posiada znacznie mniejszy współczynnik wodno-cementowy w stosunku do pierwotnego. Skutkuje to niejednorodnością w strukturze stwardniałego zaczynu cementowego na długich odcinkach w profilu otworu wiertniczego.

Podsumowując powyższe rozważania, należy stwierdzić, że nadmierna filtracja powoduje zmianę parametrów tłoczonego zaczynu, w wyniku której $[9,12,16]$ :

- istnieje możliwość wywołania szczelinowania złoża i w konsekwencji wnikania zatłoczonego zaczynu w rozszczelinowane złoże, a następnie zanik cyrkulacji;

- następuje wzrost lepkości zaczynu wskutek wcześniejszej zmiany współczynnika wodno-cementowego. Efektem powyższego jest wzrost ciśnienia tłoczenia umożliwiającego pokonanie oporów przepływu zaczynu, a następnie zagrożenie powstawania trudnych do usunięcia awarii mogących się zakończyć nieudanym zabiegiem cementowania;

- może wystąpić wzrost kosztów zabiegu cementowania poprzez wyższe zużycie cementu o $150 \div 200 \%$ w stosunku do geometrii objętości przestrzeni pierścieniowej. Takie zużycie niekiedy thumaczone jest występowaniem kawern i wnikaniem zaczynu w hydroszczeliny oraz warstwy porowate. Jest to oczywiście możliwe, jednak często zmniejszenie objętości zaczynu spowodowane jest właśnie jego nadmierną filtracją. W związku z tym niezbędne jest podejmowanie działań mających na celu obniżenie tego niepożądanego efektu.

Według API (American Petroleum Institute) filtracja zaczynu sporządzonego na czystym cemencie przekracza $1500 \mathrm{~cm}^{3} / 30 \mathrm{~min}$. Jednak wymagana podczas cementowania otworów wiertniczych filtracja nie powinna przekraczać $50 \mathrm{~cm}^{3} / 30 \mathrm{~min}$. Dla uzyskania takiej wartości stosuje się odpowiednio dobrane domieszki antyfiltracyjne do zaczynów cementowych [14].

\section{Dzialania zmierzające do obniżenia filtracji zaczynu}

Jak wspominano, filtracja zaczynu rozpoczyna się już po jego wtłoczeniu w przestrzeń pierścieniową na kontakcie zaczyn cementowy-formacja skalna. Ciecz filtruje do złoża (rysunek 4), pozostawiając cząsteczki cementu na do- tychczas przepuszczalnej warstwie formacji skalnej, efektem czego jest kolmatacja strefy przyodwiertowej. Wraz z ubytkiem fazy wodnej wzrasta również gęstość zaczynu cementowego. W celu obniżenia filtracji stosuje się domieszki do zaczynów cementowych $[7,8,11]$.

Pierwszą, a zarazem najprostszą tego rodzaju domieszką był bentonit o niskim uziarnieniu. Jego działanie polegało na wypełnianiu przestrzeni międzyziarnowych cementu. Innym rodzajem środka o podobnym mechanizmie działania doszczelniającego matrycę cementową jest emulsja polimerowa (lateks), w której znajdują się drobiny wielkości od 200 do 500 mikrometrów. Dodatkowo większość lateksów zawiera około $50 \%$ fazy stałej, która działa podobnie jak bentonit, obniżając przepuszczalność filtratu.

Nowszym rodzajem środków obniżających filtrację zaczynów cementowych są polimery rozpuszczalne w wodzie, których początek stosowania sięga roku 1940 [14]. Działanie tego rodzaju środków polega na zwiększeniu lepkości fazy wodnej i zmniejszeniu przepuszczalności osadu filtracyjnego.

Środkami mającymi minimalizować filtrację zaczynów cementowych są również pochodne celulozy. Początkowo w tym celu używane były białka otrzymywane z ziaren soi, jednak później wprowadzono środek o nazwie etylenodiaminokarboksymetyloceluloza. Wspomnieć jednak należy, że domieszki celulozowe posiadają również pewnego rodzaju wadę, którą jest mocne zagęszczanie zaczynu, a w związku z tym trudności z jego mieszaniem na skutek wzrostu lepkości plastycznej. Dodatkowo w temperaturach niższych niż $65^{\circ} \mathrm{C}$ pochodne celulozy wykazują właściwości opóźniające wiązanie zaczynu cementowego, natomiast wzrost temperatury powoduje obniżenie skuteczności działania antyfiltracyjnego. Powyższe czynniki wymusiły konieczność poszukiwania środków innego rodzaju.

Dalsze prace naukowców w placówkach badawczych skutkowały użyciem niejonowych polimerów syntetycznych w celu obniżenia filtracji zaczynów. Zastosowanie mieszaniny kopolimeru $\mathrm{N}$-winylopyrolidynowego wraz z polichlorkiem amonu umożliwiło uzyskanie zadowalających efektów, natomiast alkohol poliwinylowy pozwolił na obniżenie filtracji z wartości $500 \mathrm{~cm}^{3} / 30$ min do $10 \mathrm{~cm}^{3} / 30$ min (rysunek 4) [3, 6].

Kolejnym rodzajem środków umożliwiających obniżenie ilości filtratu w zaczynie cementowym są anionowe polimery syntetyczne, czyli częściowo hydrolizowane poliakrylamidy zawierające różne proporcje kwasu akrylowego. Związki chemiczne tego rodzaju stosowano niegdyś do kontroli filtracji w płuczkach wiertniczych, rzadziej w zaczynach cementowych, z uwagi na właściwości flokulujące. Jednak badania $z$ użyciem kopolimeru sulfonowego wykazały możliwość obniżenia filtracji z wartości $500 \mathrm{~cm}^{3}$ do mniej niż $50 \mathrm{~cm}^{3}$ (rysunek 5) [14]. 


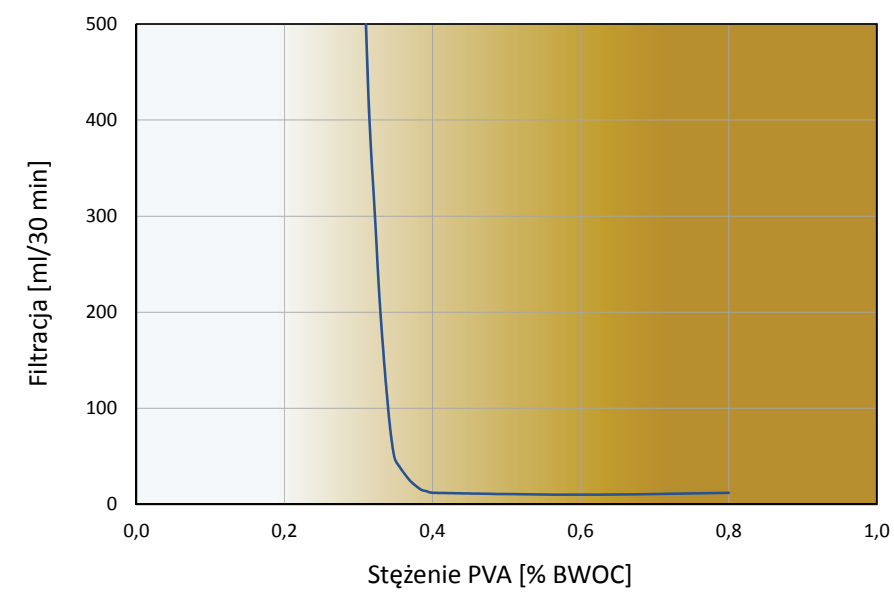

Rys. 4. Wpływ stężenia alkoholu poliwinylowego na filtrację zaczynu

Obecnie najczęściej stosowanymi środkami w celu kontroli filtracji zaczynów cementowych są polimery kationowe. Ich efektywny ciężar molekularny wynosi od 1000 do $1000000 \mathrm{~g} / \mathrm{mol}$, a struktura jest mocno rozgałęziona. W celu uzyskania znaczącego obniżenia filtracji słusznym wydaje się zastosowanie domieszki dyspergującej w połączeniu z danym polimerem. Można zauważyć, iż efektywność działania polimerów kationowych wzrasta proporcjonalnie do wzrostu ciężaru molekularnego danego polimeru, ponadto bar-

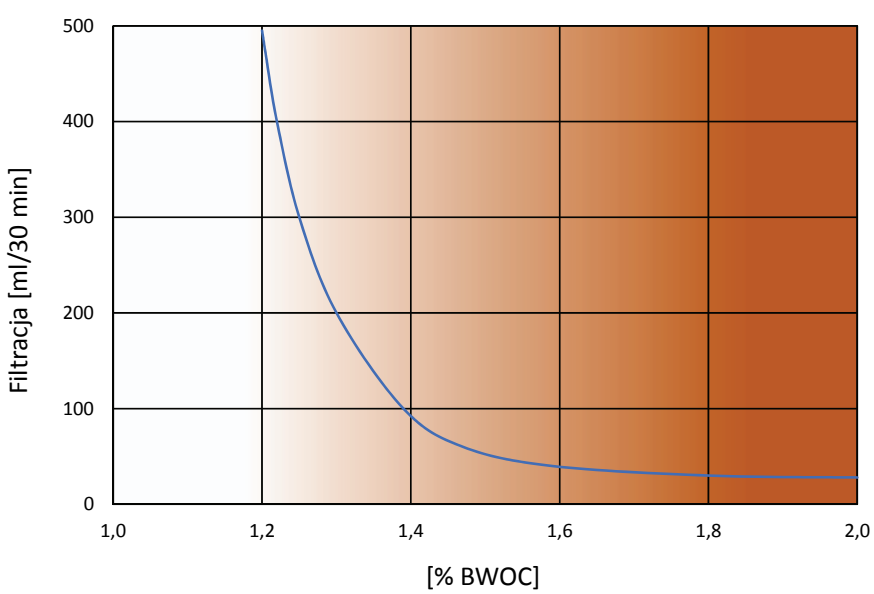

Rys. 5. Wartości filtracji zaczynów cementowych na bazie solanek z dodatkami sulfonianów

dzo pożądaną cechą jest duża efektywność działania w wysokich (dochodzących do $230^{\circ} \mathrm{C}$ ) temperaturach. Występuje również niekorzystna cecha $\mathrm{w}$ funkcjonowaniu tego rodzaju związków chemicznych, mianowicie mocne oddziaływanie sedymentacyjne. Nie jest to jednak poważny problem, ponieważ można sobie z nim w pewien sposób poradzić, niemniej jednak należy o nim pamiętać podczas modyfikowania zaczynu za pomocą środków opartych na bazie polimerów kationowych.

\section{Przebieg prac badawczych nad działaniem nowych środków antyfiltracyjnych}

Prace badawcze mające na celu określenie działania nowych środków antyfiltracyjnych do zaczynów cementowych były wykonywane w Laboratorium Zaczynów Uszczelniających INiG - PIB w oparciu o normy: PN-85/G-02320 Cementy $i$ zaczyny cementowe do cementowania $w$ otworach wiertniczych; PN-EN 10426-2 Przemyst naftowy i gazowniczy. Cementy i materialy do cementowania otworów. Część 2: Badania cementów wiertniczych oraz API SPEC 10 Specification for materials and testing for well cements.

Podczas realizowanych prac badawczych skoncentrowano się głównie na działaniu nowych środków antyfiltracyjnych. Badaniom poddane zostały cztery receptury zaczynów. Pierwsza, oznaczona symbolem BAZ (tablica 2), to zaczyn bazowy bez domieszki antyfiltracyjnej; zaczyny od 2 do 4 (oznaczone w tablicy 2 odpowiednio: DA, NA 1, NA 2) to składy z dodatkiem środków antyfiltracyjnych. Przy czym w zaczynie nr 2 (DA) zastosowano dotychczas używaną przez firmy wiertnicze domieszkę antyfiltracyjną, natomiast w recepturach 3 i 4 (NA 1, NA 2) wykorzystano nowe domieszki antyfiltracyjne proponowane do stosowania. Badania porównawcze przeprowadzone zostały dla grupy zaczynów przeznaczonych do uszczelniania kolumn rur okładzinowych na głębokościach do 250 metrów, w zakresie panu- jących temperatur do $25^{\circ} \mathrm{C}$ i przy ciśnieniu około $3 \mathrm{MPa}$. Przeprowadzono testy dla powyższych warunków otworopodobnych z uwagi na to, że niska wartość temperatury i ciśnienia sprzyja wydzielaniu się wody $z$ hydratyzującego zaczynu cementowego. Ponadto parametr filtracji w płytkich otworach jest istotny z punktu widzenia właściwości zapobiegających migracji gazu.

Receptury wytypowane do badań środków antyfiltracyjnych to zaczyny cementowe z dodatkiem $10 \%$ lateksu. Składy sporządzone zostały przy użyciu cementu portlandzkiego klasy CEM I 32,5 R. Zastosowano domieszkę 4-procentowego chlorku wapnia oraz 20-procentowego mikrocementu w celu doszczelnienia matrycy cementowej; wodą zarobową była woda wodociągowa. Analizowane receptury posiadały taki sam skład, jedyną różnicą był rodzaj użytej domieszki antyfiltracyjnej (tablica 1).

Analizując uzyskane wyniki badań, nie stwierdzono znacznego wpływu domieszek antyfiltracyjnych na gęstość zaczynu. Widoczny jest nieznaczny wzrost rozlewności zaczynu po wprowadzeniu dotychczas stosowanej domieszki antyfiltracyjnej (DA). Również nowe domieszki antyfiltracyjne NA 1 i NA 2 powodowały niewielki wzrost rozlewności (tablica 2, rysunek 6). Jest to jedna $\mathrm{z}$ informacji o działaniu 
Tablica 1. Receptury zaczynów cementowych dla warunków otworowych: temperatura $25^{\circ} \mathrm{C}$, ciśnienie $3 \mathrm{MPa}$ (składniki stałe): cement CEM 32,5 R = 100\%

\begin{tabular}{|c|c|c|c|c|c|c|c|c|c|c|}
\hline \multirow{2}{*}{ Lp. } & \multirow{2}{*}{$\begin{array}{c}\text { Skład (nr) } \\
\text { współczynnik (w/c) }\end{array}$} & \multirow{2}{*}{$\begin{array}{c}\text { Srodek } \\
\text { odpieniający }\end{array}$} & \multirow{2}{*}{$\begin{array}{c}\text { Środek } \\
\text { upłynniający }\end{array}$} & \multicolumn{3}{|c|}{ Domieszka antyfiltracyjna } & \multirow{2}{*}{ Lateks } & \multirow{2}{*}{$\begin{array}{l}\text { Stabilizator } \\
\text { lateksu }\end{array}$} & \multirow{2}{*}{$\begin{array}{l}\text { Chlorek } \\
\text { wapnia }\end{array}$} & \multirow{2}{*}{$\begin{array}{l}\text { Mikro- } \\
\text { cement }\end{array}$} \\
\hline & & & & DA & NA 1 & NA 2 & & & & \\
\hline 1. & $\mathrm{Nr} 1 \mathrm{w} / \mathrm{c}=0,52$ & 1,0 & 0,3 & - & - & - & 10,0 & 2,0 & 4,0 & 20,0 \\
\hline 2. & $\mathrm{Nr} 2 \mathrm{w} / \mathrm{c}=0,52$ & 1,0 & 0,3 & 0,1 & & - & 10,0 & 2,0 & 4,0 & 20,0 \\
\hline 3. & $\mathrm{Nr} 3 \mathrm{w} / \mathrm{c}=0,52$ & 1,0 & 0,3 & - & 0,1 & - & 10,0 & 2,0 & 4,0 & 20,0 \\
\hline 4. & $\mathrm{Nr} 4 \mathrm{w} / \mathrm{c}=0,52$ & 1,0 & 0,3 & - & - & 0,1 & 10,0 & 2,0 & 4,0 & 20,0 \\
\hline
\end{tabular}

${ }^{*}$ Współczynnik wodno-cementowy (ilość wody w stosunku do masy cementu).

Tablica 2. Parametry zaczynów cementowych dla warunków otworowych: temperatura $25^{\circ} \mathrm{C}$, ciśnienie $3 \mathrm{MPa}$

\begin{tabular}{|c|c|c|c|c|c|c|c|c|c|c|c|c|c|c|c|}
\hline \multirow{2}{*}{ 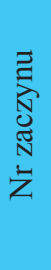 } & \multirow{2}{*}{ 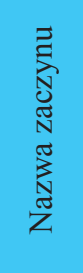 } & \multirow{2}{*}{ 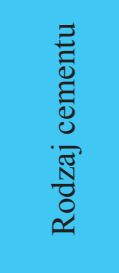 } & \multirow{2}{*}{ 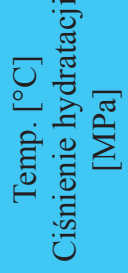 } & \multirow{2}{*}{ 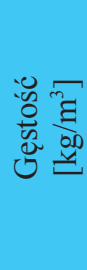 } & \multirow{2}{*}{  } & \multirow{2}{*}{$\begin{array}{l}7 \\
0 \\
\vdots \\
\vdots 0 \\
0 \\
0 \\
0 \\
0 \\
0\end{array}$} & \multirow{2}{*}{$\begin{array}{c}\text { Filtracja } \\
\\
{\left[\mathrm{cm}^{3} /\right.} \\
30 \mathrm{~min}]\end{array}$} & \multicolumn{2}{|c|}{$\begin{array}{l}\text { Czas gęstnienia }{ }^{*} \\
\text { [godz. : min] }\end{array}$} & \multicolumn{6}{|c|}{$\begin{array}{c}\text { Odczyty z aparatu Fann } \\
\text { [obr./min] }\end{array}$} \\
\hline & & & & & & & & $30 \mathrm{Bc}$ & $100 \mathrm{Bc}$ & 600 & 300 & 200 & 100 & 6 & 3 \\
\hline 1. & BAZ & \multirow{4}{*}{$\begin{array}{c}\text { Cement } \\
\text { CEM I } \\
32,5 \mathrm{R}\end{array}$} & \multirow{4}{*}{$\begin{array}{l}25^{\circ} \mathrm{C} \\
3 \mathrm{MPa}\end{array}$} & 1790 & 240 & 1,5 & 136,0 & $2: 15$ & $2: 40$ & 180 & 97 & 67 & 37 & 6 & 5 \\
\hline 2. & DA & & & 1790 & 255 & 0,5 & 6,0 & $2: 25$ & $2: 57$ & 115 & 64 & 46 & 27 & 6 & 5 \\
\hline 3. & NA 1 & & & 1800 & 260 & 2,0 & 556,0 & $2: 15$ & $2: 50$ & 141 & 85 & 69 & 49 & 25 & 19 \\
\hline 4. & NA 2 & & & 1790 & 260 & 3,0 & 774,0 & $2: 00$ & $2: 47$ & 112 & 65 & 47 & 33 & 17 & 14 \\
\hline
\end{tabular}

*czas dojścia do temperatury równy 10 minut

Tablica 3. Parametry reologiczne badanych zaczynów cementowych

\begin{tabular}{|c|c|c|c|c|c|}
\hline \multirow{2}{*}{ Model reologiczny } & \multirow{2}{*}{ Parametry reologiczne } & \multicolumn{4}{|c|}{ Zaczyn: } \\
\hline & & BAZ & DA & NA 1 & NA 2 \\
\hline \multirow{2}{*}{ Model Newtona } & Lepkość dynamiczna $[\mathrm{Pa} \cdot \mathrm{s}]$ & 0,0925 & 0,0601 & 0,0774 & 0,0597 \\
\hline & Współczynnik korelacji [-] & 0,9967 & 0,9903 & 0,8978 & 0,9437 \\
\hline \multirow{3}{*}{ Model Binghama } & Lepkość plastyczna $[\mathrm{Pa} \cdot \mathrm{s}]$ & 0,0880 & 0,0552 & 0,0595 & 0,0486 \\
\hline & Granica płynięcia $[\mathrm{Pa}]$ & 3,1645 & 3,4638 & 12,6366 & 7,8594 \\
\hline & Współczynnik korelacji [-] & 0,9994 & 0,9984 & 0,9956 & 0,9994 \\
\hline \multirow{3}{*}{ Model Ostwalda de Waele'a } & Współczynnik konsystencji $\left[\mathrm{Pa} \cdot \mathrm{s}^{\mathrm{n}}\right]$ & 0,7125 & 0,8516 & 5,3964 & 3,6758 \\
\hline & Wykładnik potęgowy [-] & 0,6760 & 0,5826 & 0,3395 & 0,3515 \\
\hline & Współczynnik korelacji [-] & 0,9786 & 0,9721 & 0,9446 & 0,9157 \\
\hline \multirow{3}{*}{ Model Cassona } & Lepkość Cassona $[\mathrm{Pa} \cdot \mathrm{s}]$ & 0,0732 & 0,0418 & 0,0299 & 0,0252 \\
\hline & Granica płynięcia $[\mathrm{Pa}]$ & 0,8158 & 1,1994 & 7,9091 & 5,0177 \\
\hline & Współczynnik korelacji [-] & 0,9990 & 0,9999 & 0,9976 & 0,9924 \\
\hline \multirow{4}{*}{ Model Herschela-Bulkleya } & Granica płynięcia $[\mathrm{Pa}]$ & 1,8175 & 2,0833 & 10,3474 & 7,5300 \\
\hline & Współczynnik konsystencji $\left[\mathrm{Pa} \cdot \mathrm{s}^{\mathrm{n}}\right]$ & 0,1472 & 0,1235 & 0,1924 & 0,0615 \\
\hline & Wykładnik potęgowy [-] & 0,9263 & 0,8844 & 0,8318 & 0,9660 \\
\hline & Współczynnik korelacji [-] & 1,0000 & 1,0000 & 0,9989 & 0,9995 \\
\hline
\end{tabular}

dyspergującym badanych środków i obniżeniu lepkości zaczynu oraz jego współczynnika konsystencji. Wprowadzenie do zaczynu dotychczas stosowanej domieszki antyfiltracyjnej (DA) skutkowało wzrostem czasu gęstnienia zaczynu. Uzyskano początek czasu gęstnienia (30 Bc) o 10 mi- nut dłuższy w stosunku do zaczynu bazowego i koniec czasu gęstnienia (100 Bc) o 17 minut dłuższy w odniesieniu do zaczynu bazowego (BAZ) (tablica 2, rysunek 7). Nowa domieszka antyfiltracyjna NA 1 nie spowodowała zmiany początku czasu gęstnienia, natomiast koniec czasu gęstnienia 


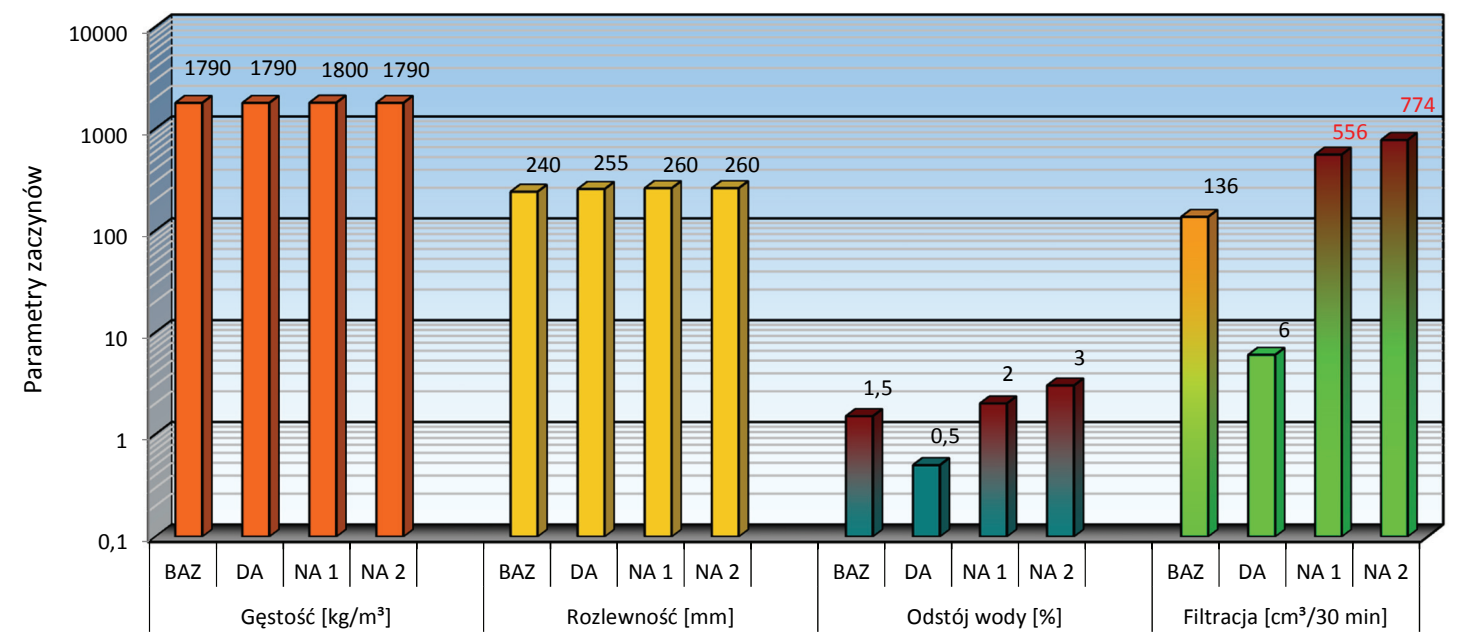

Rys. 6. Parametry porównywanych zaczynów cementowych

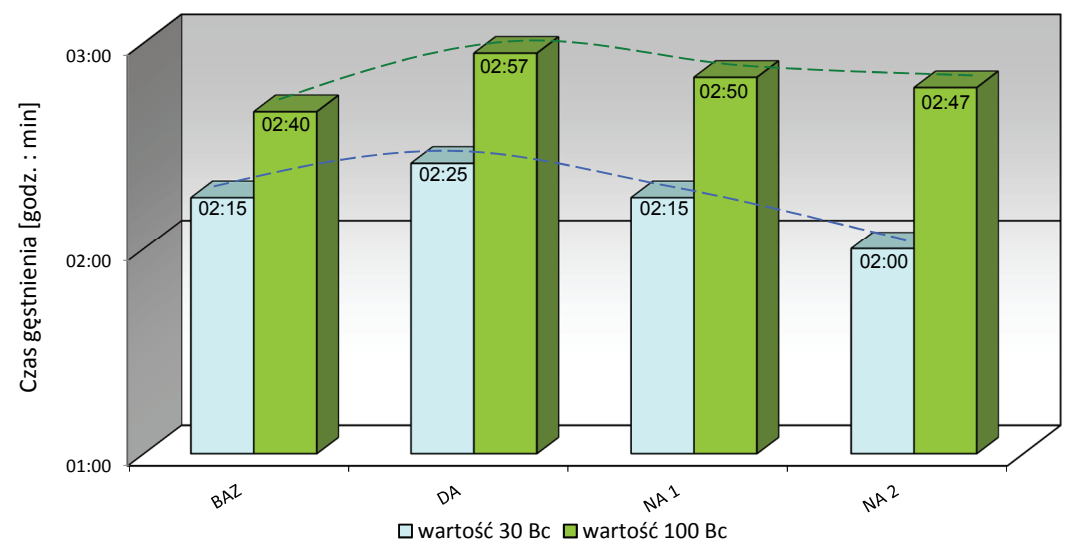

Rys. 7. Czas gęstnienia porównywanych zaczynów cementowych

domieszek antyfiltracyjnych NA 1 i NA 2. Dotychczas stosowany antyfiltrat DA spowodował obniżenie filtracji z wartości $136 \mathrm{~cm}^{3} / 30 \mathrm{~min}$ w zaczynie bazowym do $6 \mathrm{~cm}^{3} / 30 \mathrm{~min}$ - co jest bardzo korzystne. Natomiast po zastosowaniu domieszek antyfiltracyjnych NA 1 i NA 2 filtracja wzrosła do wartości odpowiednio: $556 \mathrm{~cm}^{3} / 30 \mathrm{~min}$ oraz $774 \mathrm{~cm}^{3} / 30$ min (rysunek 6). Są to bardzo duże wartości, w związku z czym stwierdzono, że udostępnione do badań produkty nie tylko nie przynoszą oczekiwanego efektu prac, ale znacznie pogarszają taki parametr zaczynu jak filtracja. Ponadto badane środki antyfiltracyjne spowodowały

uległ wzrostowi o 10 minut. Domieszka NA 2 przyczyniła się do skrócenia początku czasu gęstnienia o 15 minut w stosunku do zaczynu bazowego oraz niewielkie (7-minutowe) wydłużenie końca czasu gęstnienia. Zauważalne jest wydłużenie czasu przejścia od wartości $30 \mathrm{Bc}$ do $100 \mathrm{Bc}$ po wprowadzeniu domieszek antyfiltracyjnych, co może być wynikiem działania dyspergującego stosowanych środków antyfiltracyjnych. Wartości zestawiono w tablicy 2 oraz na rysunku 7. Analizując wartości parametrów reologicznych w nawiązaniu do wspomnianego pomiaru rozlewności, zaobserwować można wpływ działania domieszek antyfiltracyjnych na obniżenie lepkości plastycznej ${ }_{\mathrm{Css}}$. Najmniejszy wpływ na lepkość plastyczną wykazywała domieszka antyfiltracyjna DA, natomiast najmocniejsze upłynnienie zaczynu uzyskano, stosując domieszkę NA 2 (rysunek 8). Wykorzystane domieszki powodują wzrost granicy płynięcia (rysunek 8), czego konsekwencją może być wzrost oporów przepływu tłoczonego zaczynu.

Przechodząc do porównania kluczowych parametrów, które powinny regulować domieszki antyfiltracyjne, stwierdzono znaczny wzrost wartości filtracji po wprowadzeniu nowych również wzrost wartości odstoju wody, który jest także niekorzystny podczas projektowania receptury zaczynu przeznaczonego do uszczelniania kolumn rur okładzinowych.

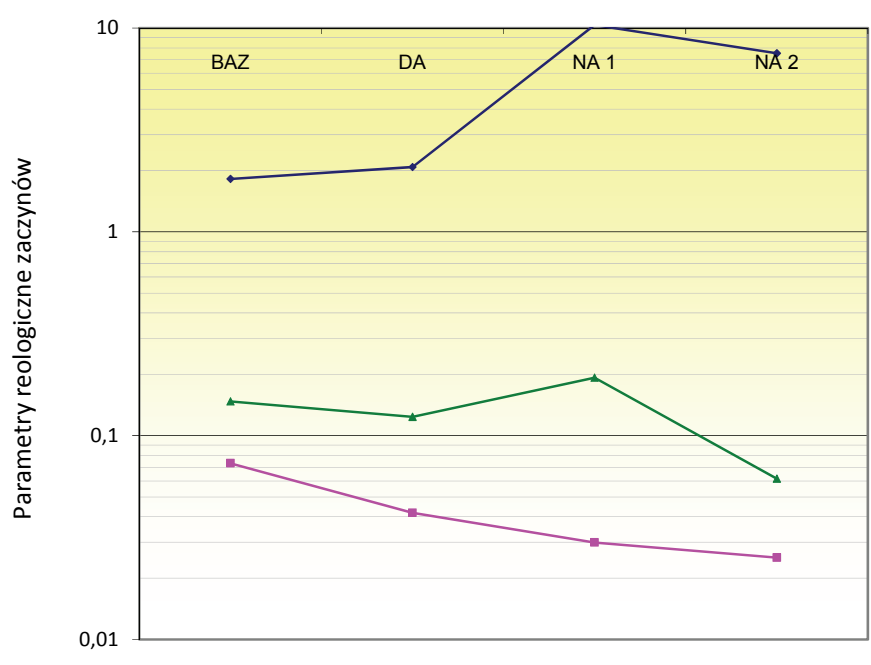

$\longrightarrow$ Granica płynięcia $[\mathrm{Pa}] \longrightarrow$ Lepkość Css $[\mathrm{Pa} \cdot \mathrm{s}] \longrightarrow$ Współczynnik konsys. $\left[\mathrm{Pa} \cdot \mathrm{s}^{\mathrm{n}}\right]$

Rys. 8. Zestawienie wyników badań parametrów reologicznych zaczynów cementowych 
Analizując uzyskane wyniki badań, jednoznacznie stwierdzono, że nowe środki antyfiltracyjne nie są efektywne w sporządzonych zaczynach cementowych. Powodują one znaczny wzrost wartości filtracji zaczynu. Nie należy jednak podważać słuszności użycia danych pro- duktów, ponieważ powyższe działanie może być skutkiem braku kompatybilności z innymi domieszkami stosowanymi w recepturze danego zaczynu. W tym celu należy przeprowadzić szereg dodatkowych badań, które obecnie są $\mathrm{w}$ trakcie realizacji.

\section{Wnioski}

Analizując uzyskane wyniki badań, wyciągnięto następujące wnioski:

1. Dodatek nowych środków antyfiltracyjnych spowodował bardzo mocne zwiększenie wartości filtracji modyfikowanego zaczynu cementowego. Uzyskano ponad pięciokrotny wzrost wartości filtracji w porównaniu z zaczynem bazowym, gdzie dotychczas stosowana domieszka antyfiltracyjna obniżyła filtrację ponad 22-krotnie (rysunek 6).

2. Nowa domieszka antyfiltracyjna spowodowała zwiększenie ilości odstoju wody w porównaniu z zaczynem bazowym (rysunek 6).

3. Stosowane domieszki antyfiltracyjne nie wywołały zmiany gęstości zaczynów cementowych, a rozlewność zaczynów zawarta była w porównywalnym zakresie $240 \div 260 \mathrm{~mm}$ (rysunek 6).

4. Stosowanie domieszki antyfiltracyjnej skutkuje wydłużeniem czasu początku gęstnienia oraz czasu końca gęstnienia (rysunek 7). Należy mieć na uwadze takie zachowanie projektowanego zaczynu i w związku z powyższym uwzględniać potrzebę zastosowania dodatkowych środków regulujących czas gęstnienia.

5. Korzystnym działaniem domieszek antyfiltracyjnych jest obniżenie lepkości plastycznej zaczynów cementowych i niekiedy współczynnika konsystencji. Jednak udostępnione do badań produkty spowodowały wzrost granicy płynięcia (rysunek 8), którego konsekwencją może być utrudniona przetłaczalność zaczynu.
6. Ze względu na niekiedy zaskakujące wyniki badań, nowe domieszki do zaczynów uszczelniających muszą być bezwzględnie poddawane badaniom laboratoryjnym na specjalistycznej aparaturze.

7. Przedstawione wyniki zrealizowanych prac badawczych potwierdzają konieczność prowadzenia dalszych badań dla nowych środków modyfikujących parametry zaczynów cementowych.

Konkludując, stwierdza się, iż niezbędne jest prowadzenie badań nad nowymi proponowanymi do zastosowania środkami do zaczynów uszczelniających. Tego rodzaju prace badawcze są od wielu lat wykonywane w Instytucie Nafty i Gazu - Państwowym Instytucie Badawczym.

Oczywiście nie należy definitywnie przekreślać możliwości stosowania danego środka chemicznego. Przedstawione powyżej działanie może być wynikiem braku kompatybilności związków chemicznych zastosowanych do produkcji danej domieszki z innymi substancjami regulującymi parametry technologiczne badanego zaczynu cementowego. Aby się o tym przekonać, należy przeprowadzić dodatkową serię czasochłonnych badań, które obecnie są wykonywane w INiG - PIB. Efektem finalnym prowadzonych prac będzie określenie możliwości stosowania różnych rodzajów środków antyfiltracyjnych w zaczynach cementowych oraz opracowanie receptur zaczynów o niskiej wartości filtracji, które będą charakteryzować się odpowiednimi parametrami technologicznymi.

Prosimy cytować jako: Nafta-Gaz 2017, nr 8, s. 583-590, DOI: 10.18668/NG.2017.08.05

Artykuł nadesłano do Redakcji 16.03.2017 r. Zatwierdzono do druku 24.05.2017 r.

Artykuł powstał na podstawie pracy badawczej pt.: Analiza możliwości poprawy efektywności uszczelniania rur okładzinowych poprzez zastosowanie nowych dodatków do zaczynów cementowych - praca INiG - PIB na zlecenie MNiSW; nr zlecenia: 35/ KW/15, nr archiwalny: DK-4100/35/15.

\section{Literatura}

[1] Barron A.R.: Hydratation of Portland Cement; http://cnx.org/ content/m16447/latest/ (dostęp: 26.01.2010).

[2] Bonett A., Pafitis D.: Getting to the Root of Gas Migration. Oilfield Review, Spring 1996.

[3] Carpenter R.B.: Matrix Control Cementing Slurry. U.S. Patent No. 4.569.395, 1986.

[4] Gawlik P., Szymczak M.: Migracje gazowe w przestrzeniach międzyrurowych otworów realizowanych na Przedgórzu Karpat. Nafta-Gaz 2006, nr 7-8, s. 349-358.
[5] Habrat S., Raczkowski J., Zawada S.: Technika i technologia cementowań $w$ wiertnictwie. Wydawnictwo Geologiczne, Warszawa 1980.

[6] Harrison H.T.: Aqueous Cementing Composition Adaptable to High Turbulent Flow and Method of Cementing a Well Using Same. U.S. Patent No. 3.409.080, 1968.

[7] Kasza P.: Laboratoryjne badania filtracji cieczy szczelinujacych. Nafta-Gaz 2005, nr 12, s. 531-537.

[8] Kremieniewski M.: Ograniczenie ekshalacji gazu w otworach 
wiertniczych poprzez modyfikację receptur oraz ksztaltowanie się struktury stwardniałych zaczynów uszczelniajacych. Prace Naukowe Instytutu Nafty i Gazu - Państwowego Instytutu Badawczego 2016, nr 199.

[9] Kremieniewski M., Stryczek S., Kotwica Ł.: Zmiany w mikrostrukturze płaszcza cementowego w zależności od warunków hydratacji zaczynu. Nafta-Gaz 2014, nr 12, s. 918-926.

[10] Kremieniewski M., Rzepka M., Stryczek S., Wiśniowski R., Kotwica Ł., Złotkowski A.: Korelacja przepuszczalności i parametrów opisujacych strukturę stwardniałych zaczynów cementowych stosowanych do uszczelniania otworów w rejonie Basenu Pomorskiego. Nafta-Gaz 2015, nr 10, s. 737-746.

[11] Kremieniewski M., Rzepka M.: Zaczyny typu Gas-Stop przeznaczone do uszczelniania otworów kierunkowych $i$ horyzontalnych. Wiadomości Naftowe i Gazownicze 2013, nr 9, s. 4-9.

[12] Levine D.C., Thomas E.W., Bezner H.P., Talle G.C.: Annular Gas Flow After Cementing: A Look at Practical Solutions. Paper SPE 8255, 1979.

[13] Łaczek T.: Filtracja jako metoda oceny jakości FAME. Nafta-Gaz 2011, nr 11, s. 831-836.

[14] Nelson E.B. et al.: Well Cementing. Schlumberger Educational Service, Houston, Teksas, USA, 1990.

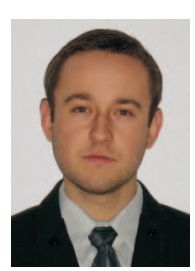

Dr inż. Marcin KREMIENIEWSKI

Adiunkt w Zakładzie Technologii Wiercenia.

Instytut Nafty i Gazu - Państwowy Instytut Badawczy

ul. Lubicz 25 A

31-503 Kraków

E-mail: marcin.kremieniewski@inig.pl
[15] Nowe aplikacje w zakresie udostępniania i eksploatacji złóż węglowodorów otworami kierunkowymi i poziomymi. Praca zbiorowa. Prace INiG 2008, nr 152.

[16] Raczkowski J., Stryczek S., Fugiel K., Kraj Ł., Wilk S.: Zaczyny do uszczelniania w otworach wiertniczych. AGH, Skrypty uczelnianie nr 612, Kraków 1978.

[17] Rogers M.J., Dillenbeck R.L., Eid R.N.: Transition Time of Cement Slurries, Definitions and Misconceptions, Related to Annular Fluid Migration. SPE Annual Technical Conference and Exhibition, Houston, Texas, 26-29 September 2004.

[18] Rzeczpospolita lupkowa. Studium wiedzy o gazie z formacji lupkowych. Praca zbiorowa. Prace Naukowe INiG 2012, nr 183.

[19] Stryczek S., Wiśniowski R., Gonet A., Złotkowski A.: The influence of time of rheological parameters of fresh cement slurries. AGH Drilling, Oil, Gas 2014, vol. 31, s. 123-133.

[20] Studia nad doborem zaczynów uszczelniajacych $w$ warunkach wierceń $w$ basenie pomorskim. Praca zbiorowa pod red. S. Stryczka. Prace AGH, Kraków 2016.

[21] Tarabani S., Hareland G.: New cement additives that eliminate cement body permeability. SPE 29269, 20-22 March 1995.

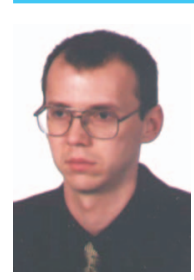

Dr inż. Marcin RZEPKA

Kierownik Laboratorium Zaczynów Uszczelniających w Zakładzie Technologii Wiercenia.

Instytut Nafty i Gazu - Państwowy Instytut Badawczy ul. Lubicz 25 A

31-503 Kraków

E-mail: marcin.rzepka@inig.pl

\section{OFERTA}

\section{ZAKŁAD TECHNOLOGII WIERCENIA}

Zakres działania:

- $\quad$ opracowywanie składów i technologii sporządzania płuczek wiertniczych, cieczy do dowiercania, opróbowania i rekonstrukcji odwiertów, zaczynów cementowych i mieszanin wiążących dla różnych warunków geologiczno-technicznych wiercenia;

- $\quad$ kompleksowe badania i ocena nowych rodzajów środków chemicznych, materiałów płuczkowych i wiążących, przeznaczonych do sporządzania i regulowania właściwości płuczek wiertniczych i zaczynów cementowych;

- $\quad$ pomiary parametrów technologicznych cieczy wiertniczych i kamienia cementowego w warunkach normalnej i wysokiej temperatury oraz ciśnienia;

- $\quad$ badania wpływu płuczek wiertniczych na przewiercane skały;

- dobór płuczek wiertniczych, zaczynów cementowych, cieczy buforowych w celu poprawy skuteczności cementowania otworów wiertniczych;

- $\quad$ badania serwisowe dla bieżących zabiegów cementowania;

- $\quad$ specjalistyczne badania laboratoryjne dotyczące oznaczania: współczynnika tarcia cieczy wiert-

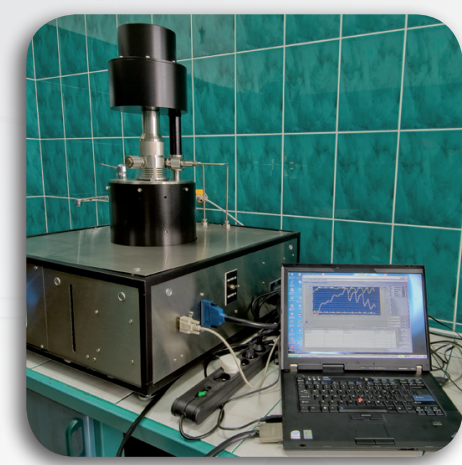
niczych i napięcia powierzchniowego na granicy faz, czystości i temperatury krystalizacji solanek, typu emulsji, sedymentacji fazy stałej, efektywności wynoszenia zwiercin w otworach kierunkowych i poziomych oraz wypłukiwania osadów iłowych ze skał przed zabiegiem cementowania, odporności na migrację gazu w wiążącym zaczynie cementowym w warunkach otworopodobnych, wczesnej wytrzymałości na ściskanie kamienia cementowego, odporności korozyjnej kamienia cementowego w różnym środowisku złożowym, porowatości oraz przepuszczalności dla gazu kamienia cementowego i skał, zawartości związków chemicznych w cieczach wiertniczych, stopnia toksyczności środków chemicznych i cieczy wiertniczych przy użyciu bakterii bioindykatorów;

- $\quad$ badania właściwości fizyczno-mechanicznych skał pod kątem ich zwiercalności.

Kierownik: dr inż. Małgorzata Uliasz

Adres: ul. Armii Krajowej 3, 38-400 Krosno

Telefon: 134368941 w. 5219

Faks: 134367971

E- mail: malgorzata.uliasz@inig.pl
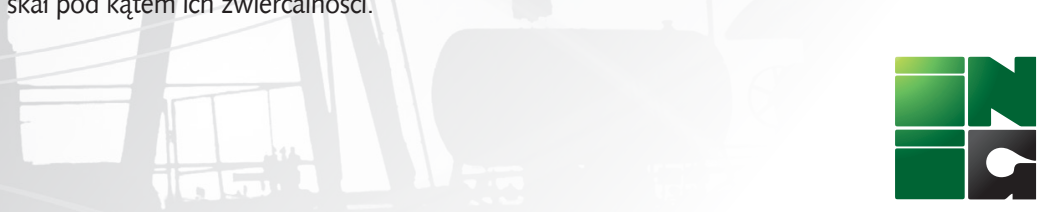